\title{
Intracellular Immunohistochemical Detection of Tetrodotoxin in Pleurobranchaea maculata (Gastropoda) and Stylochoplana sp. (Turbellaria)
}

\section{Lauren R. Salvitti ${ }^{1}$, Susanna A. Wood ${ }^{1,2}$, Leigh Winsor $^{3}$ and Stephen Craig Cary ${ }^{1, *}$}

1 Department of Biological Sciences, University of Waikato, Private Bag 3105, Hamilton 3240, New Zealand; E-Mails: 1s161@students.waikato.ac.nz (L.R.S.); susie.wood@cawthron.org.nz (S.A.W.)

2 Cawthron Institute, Nelson 7042, New Zealand

3 College of Marine and Environmental Sciences, James Cook University, Townsville QLD 4811, Australia; E-Mail: leigh.winsor@jcu.edu.au

* Author to whom correspondence should be addressed; E-Mail: caryc@waikato.ac.nz; Tel.: +64-7-838-4593.

Academic Editor: Eric Blomme

Received: 12 December 2014 / Accepted: 23 January 2015 / Published: 28 January 2015

\begin{abstract}
Tetrodotoxin (TTX), is a potent neurotoxin targeting sodium channels that has been identified in multiple marine and terrestrial organisms. It was recently detected in the Opisthobranch Pleurobranchaea maculata and a Platyhelminthes Stylochoplana sp. from New Zealand. Knowledge on the distribution of TTX within these organisms is important to assist in elucidating the origin and ecological role of this toxin. Intracellular micro-distribution of TTX was investigated using a monoclonal antibody-based immunoenzymatic technique. Tetrodotoxin was strongly localized in neutral mucin cells and the basement membrane of the mantle, the oocytes and follicles of the gonad tissue, and in the digestive tissue of P. maculata. The ova and pharynx were the only two structures to contain TTX in Stylochoplana sp. Using liquid chromatography-mass spectrometry, TTX was identified in the larvae and eggs, but not the gelatinous egg cases of P. maculata. Tetrodotoxin was present in egg masses of Stylochoplana sp. These data suggest that TTX has a defensive function in adult $P$. maculata, who then invest this in their progeny for protection. Localization in the digestive tissue of $P$. maculata potentially indicates a dietary source of TTX. Stylochoplana sp. may use TTX in prey capture and for the protection of offspring.
\end{abstract}


Keywords: Pleurobranchaea maculata; Stylochoplana sp.; tetrodotoxin; immunohistochemistry; monoclonal antibody

\section{Introduction}

Tetrodotoxin (TTX) is a potent non-protein neurotoxin that selectively targets and blocks voltage-gated sodium channels. It is most notably found in the tissues of pufferfish species from the Tetraodontidae family [1,2]. Tetrodotoxin is fatal to humans (wt. $50 \mathrm{~kg}$ ) at levels of just 1-2 $\mathrm{mg}$ [3]. Tetrodotoxin was initially thought to only occur in pufferfish, but has since been discovered in a growing number of organisms including frogs, newts, gastropods, crabs, an algae species, arrow worms, and land planarians $[2,4-6]$.

Numerous researchers have suggested that the incidence of TTX in so many genetically unrelated organisms is due to an exogenous source such as symbiotic bacterial production or bioaccumulation through diet [2,7-9]. Bioaccumulation of TTX has been implicated in several instances in which prey animals have also been shown to contain TTX, or during captive studies where organisms removed from their natural environments lose their toxicity [1,10-12]. In contrast, bacterial production of TTX has also been reported in marine organisms including the gastropod Niotha clathrata [13], the blue-ringed octopus Octopus maculosus (i.e., Hapalochlaena maculosa) [14], and the pufferfish Fugu vermicularis vermicularis [15]. However, concentrations of toxin produced by isolated bacterial strains are generally orders of magnitude lower than host organisms, suggesting bacterial production is unlikely to be the sole source of toxin $[7,8,16]$. In contrast, studies on terrestrial newts (Taricha granulosa) showed an increase in toxin concentrations when kept in captivity and the ability to regenerate TTX after the release of toxin through the skin, suggesting an endogenous source $[17,18]$. Currently the definitive origin of TTX remains debated, and strategies for acquisition most likely vary among species.

Studies using chemical methods to detect TTX have shown sequestration of toxin varies among tissue types in many organisms [2]. For example, in the pufferfish Takifugu niphobles high concentrations of TTX were present in the liver, ovaries, and intestines, while skin and muscle tissues only had low concentrations [1]. Micro-distribution of TTX has been demonstrated using TTX specific monoclonal antibody (mAB) immunoenzymatic techniques in newts [19,20], ribbon and flat worms [21], pufferfish [22-24], and octopuses [25]. Understanding the accumulation and sequestration of TTX at the cellular level provides additional information regarding the ecological functions of TTX. For example, in predator-prey trials conducted by Williams et al. [26] using the rough-skinned newts, Taricha granulosa and their natural predator the garter snake Thamnophis sirtalis, it was shown that rejected newts possessed significantly higher concentrations of TTX in the skin compared to those that were consumed.

In 2009, the opisthobranch Pleurobranchaea maculata was found to contain high concentrations of TTX when a number of dogs became ill after consuming beach-cast individuals in New Zealand [27]. Subsequent studies using liquid chromatography-mass spectrometry (LC-MS) revealed that only the TTX variant was present. The highest concentrations of TTX were in the mantle, gonad, and digestive 
tissue, with total TTX concentrations (highest average (ave.) $369 \mathrm{mg} \cdot \mathrm{kg}^{-1}$ ) varying significantly between individuals and season $[12,28]$. Using a series of aquaria based studies, the egg-laying season was shown to coincide with seasonal peaks in TTX concentrations (June-August) [28]. The high concentrations of TTX detected in egg masses, and the subsequent depuration of TTX from adults after spawning, suggest that TTX plays a protective role in offspring of P. maculata. In 2013, high concentrations (ave. $376 \mathrm{mg} \cdot \mathrm{kg}^{-1}$ ) of TTX were detected in Stylochoplana sp. (a marine flatworm), collected from Tauranga, New Zealand [29]. Concentrations of TTX were less variable than in $P$. maculata, but also decreased from winter (June-August) to spring (September to November). The small size of Stylochoplana sp. (ca. $60 \mathrm{mg}$ ) prohibited dissection and LC-MS analysis of TTX concentrations in various tissues, thus to date there is no information on how TTX is distributed within this organism. In this study immunohistological techniques, in conjunction with the T20G10 anti-TTX monoclonal antibody (mAB) [30], were used to investigate the micro-distributions of TTX within each organism at the cellular level. These data may provide insights on ecological function and the source of TTX in these organisms.

\section{Results and Discussion}

\subsection{Pleurobranchaea Maculata}

\subsubsection{Mantle}

Species from the group Opisthobranchia have extremely reduced, or in some cases have completely lost, their protective shell, resulting in a diverse range of alternative defensive strategies [31-33]. These include the acidification of the mantle [33-35], incorporation of nematocysts from cnidarian prey [31], development of spicules [36], secretion of ink [37], and acquisition of secondary metabolites [32,38]. The mantle, or dorsal body wall, of $P$. maculata consists of multiple folds or puckering of the epidermis which has previously been reported to be extremely acidic ( $\mathrm{pH}=1$ to 2) [39]. In the immunostained section of the mantle TTX, visualized as brown color deposits, was most strongly localized in the basement membrane layer as well as in tear-shaped membrane bound cells (Figure 1A). This is similar to immunohistochemical studies on the pufferfish Tetraodon nigroviridis [22], Tetraodon steindachneri [24], and Takifugu niphobles [40] where TTX was shown to be sequestered in both basal cells and succiform cells of the epidermis. The pink color of the tear-shaped cells in both the Hematoxylin \& Eosin (H\&E) and the Alcian Blue-Periodic Acid Schiff (AB-PAS) stained sections reveal that these erythrophil cells secrete neutral mucin, suggesting that cells responsible for the acidity of the mantle and sequestration of TTX are separate. Sequestration of TTX in the skin has been reported in a number of other organisms including the pufferfish Takifugu vermicularis and Chelonodon patoca, [23], the California newt Taricha torosa [41], red-spotted newt, Notophthalmus viridescens [19], the Japanese newt Cynops pyrrhogaster [20], and the frog Brachycephalus ephippium [42], and a possible defensive mechanism is suggested. 


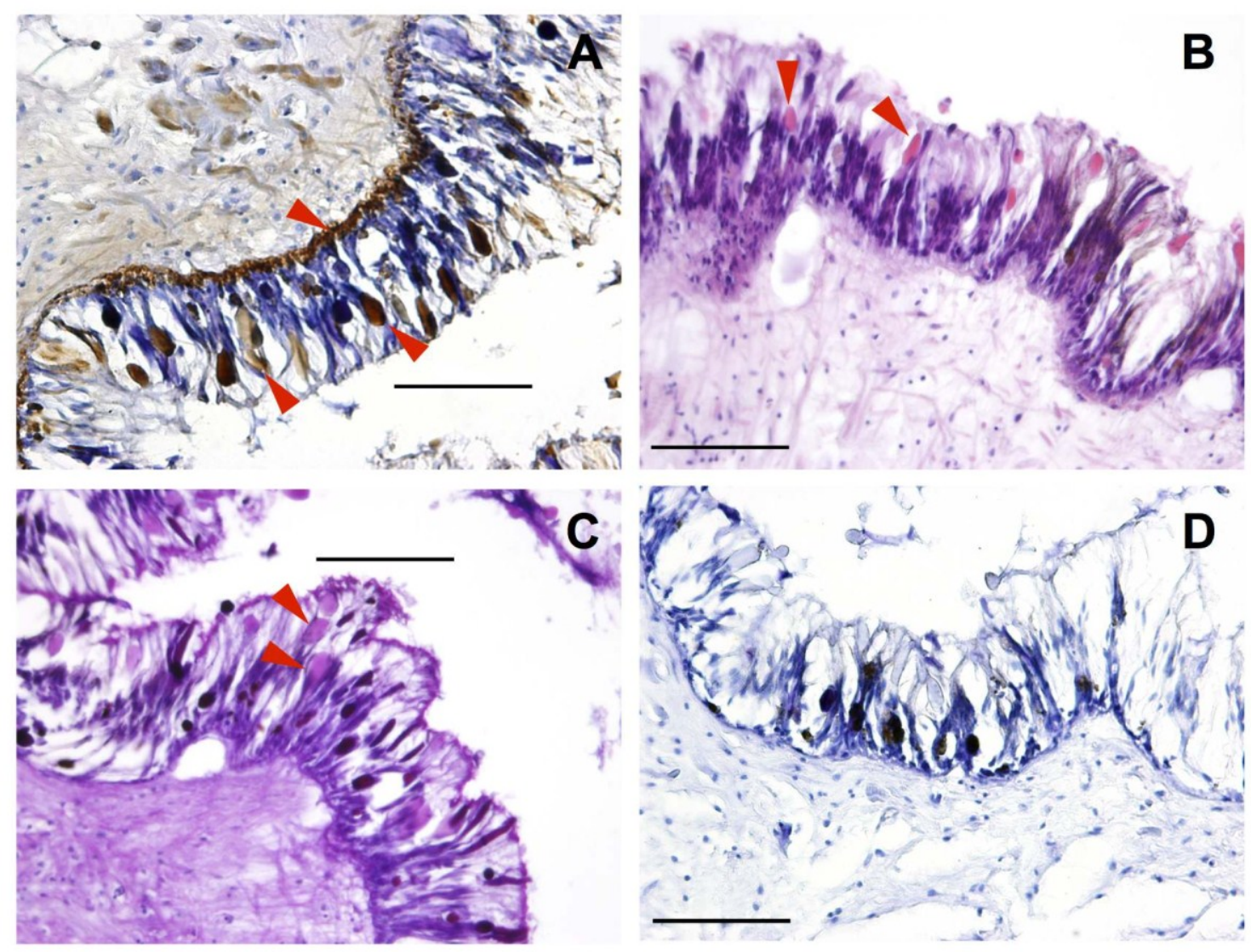

Figure 1. Pleurobranchaea maculata mantle tissue sectioned at $10 \mu \mathrm{m}$. Red arrows indicate tetrodotoxin (TTX) containing cells. (A) TTX-specific monoclonal antibody (mAB) immunohistological staining (TTX identified by the brown color deposits); (B) Hematoxylin and Eosin staining; (C) Alcian Blue-Periodic Acid Schiff staining and; (D) $\mathrm{mAB}$ negative control. Black bars $=100 \mu \mathrm{m}$.

\subsubsection{Reproductive and Digestive Tissue}

Analysis of the mAB incubation of the gonad and digestive tissue from P. maculata showed the strongest antigen-antibody reaction was in the oocytes and their surrounding follicles (Figure 2A). Positive staining occurred to a lesser degree in the digestive gland (Figure 2A). Localization of TTX in the reproductive organs/tissues has been observed in other organisms including the oocytes of pufferfish Takifugu niphobles [40], Takifugu vermicularis and Chelonodon patoca [23], the ovaries, oviduct, and testis of the short-tailed newt Cynops ensicauda [43], and the ovaries of the blue ringed octopuses Hapalochlaena lunulata and Hapalochlaena fasciata [44]. Researchers have suggested that TTX plays a protective role in host organisms, and the localization of TTX in reproductive organs imparts the toxin onto offspring to increase their survival rates [44,45].

Previous reports addressing the origin of TTX in P. maculata have provided evidence suggesting that a dietary source is probable [12,29,46]. A dietary source was suggested by Wood et al. [12] due to the depuration of TTX in P. maculata when kept in captivity and fed a non-toxic diet. Khor et al. [46] demonstrated that non-toxic $P$. maculata have the ability to sequester TTX into their tissues when fed an artificial toxic food source. Further evidence was provided when real-time PCR assays revealed 
P. maculata ingested the co-existing TTX-containing Stylochoplana sp. [29]. Collectively these studies suggest that TTX in P. maculata is most likely obtained from a dietary source. The localization of TTX in the digestive gland tissue of $P$. maculata supports this proposed scenario (Figure 2A).

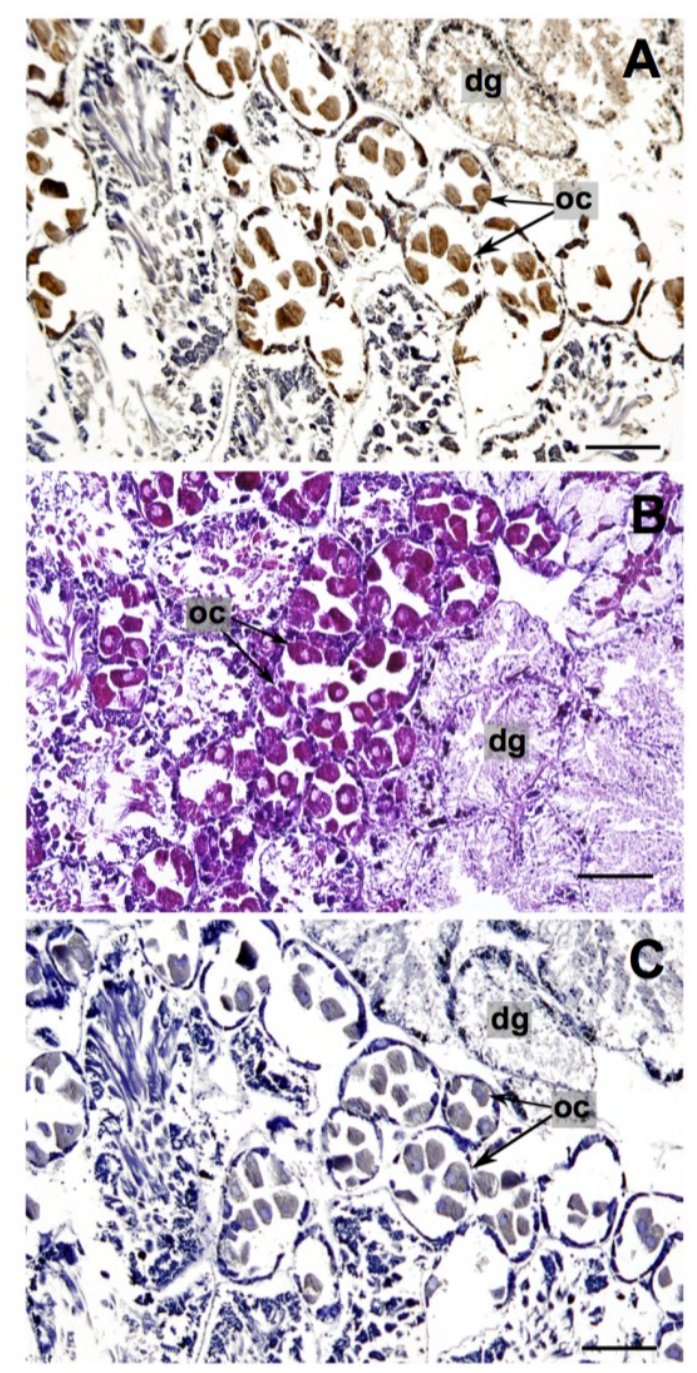

Figure 2. Pleurobranchaea maculata gonad/digestive tissue sectioned at $10 \mu \mathrm{m}$. (A) Tetrodotoxin (TTX)-specific monoclonal antibody (mAB) immunohistological staining (TTX identified by the brown color deposits); (B) Hematoxylin and Eosin staining; and (C) $\mathrm{mAB}$ negative control. $\mathrm{dg}=$ digestive gland, $\mathrm{oc}=$ oocyte. Black bars $=200 \mu \mathrm{m}$.

\subsection{Stylochoplana sp.}

Stylochoplana sp. were fixed flat and sectioned dorsoventrally. Tetrodotoxin, identified by the brown color deposits, is contained in the ova as well as portions of the pharynx (Figure 3). The localization of TTX in the reproductive and digestive tissues has also been reported in other flatworm species. Tanu et al. [21] used immunohistological techniques to show that TTX was contained in the ovum of the flatworm Planocera reticulata. Miyazawa et al. [47] showed the oviduct and digestive organs to be the most toxic tissues in the flatworm Planocera multitentaculata via mouse bioassay. A study on a planocerid species found on a reef in Guam demonstrated the highest concentrations of TTX were in the pharynx and through a series of feeding studies the researchers suggested that TTX 
was utilized in prey capture [48]. The sequestration of TTX in the pharynx of Stylochoplana sp. suggests this species may also use it to capture prey. The detection of TTX in the ova corroborates the observation of TTX in reproductive structures of Pleurobranchaea maculata, as well as many TTX-containing organisms, and most likely acts as a protective mechanism in offspring (see earlier discussion).

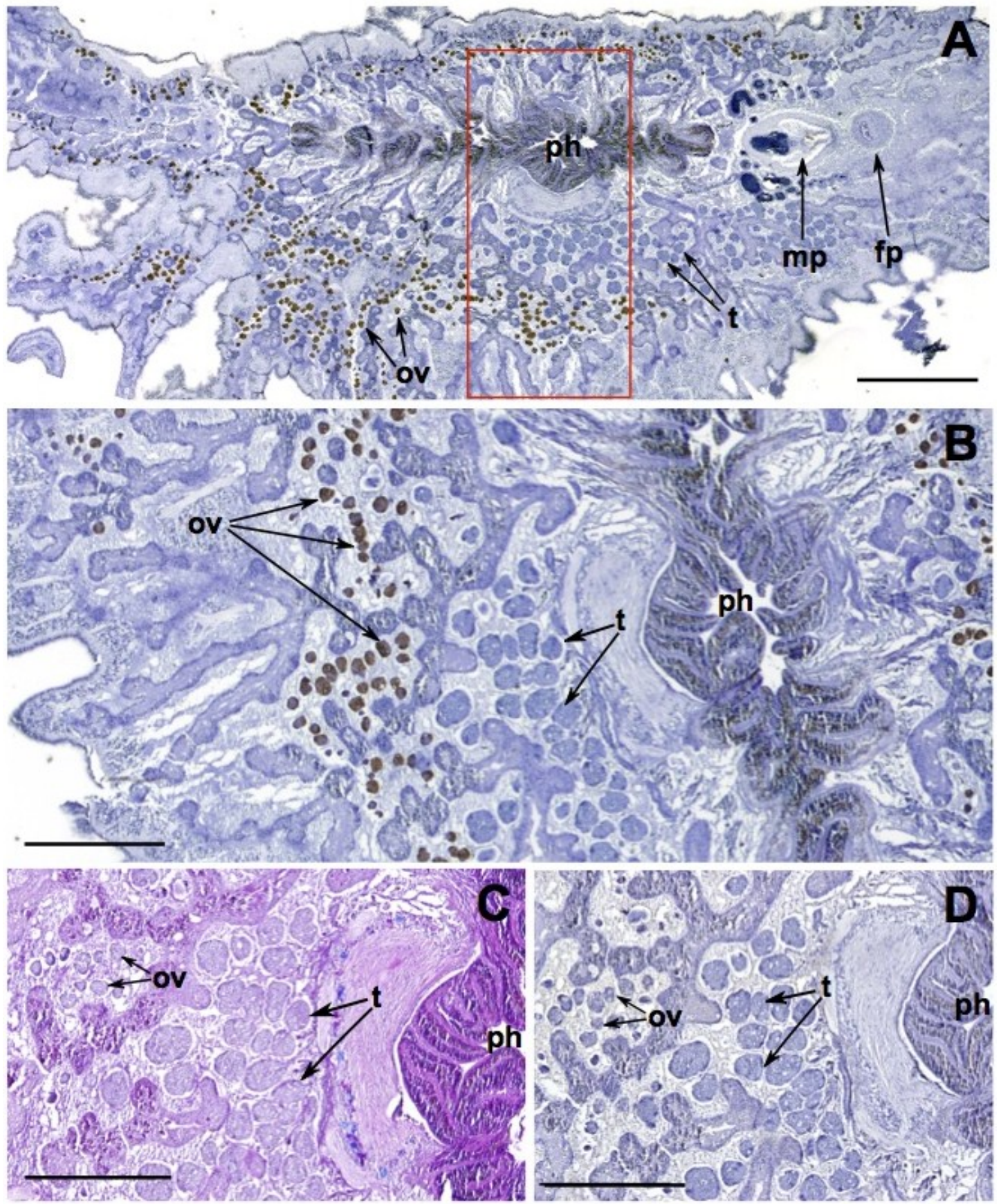

Figure 3. Stylochoplana sp. dorsoventral view sectioned at $7 \mu \mathrm{m}$. (A) Tetrodotoxin (TTX)-specific monoclonal antibody (mAB) immunohistological staining, (TTX identified by the brown color deposits) (B) Enlargement and $90^{\circ}$ rotation of red box on A to show detailed view of ova, testes, and pharynx, (C) Alcian Blue-Periodic Acid Schiff staining, and, (D) $\mathrm{mAB}$ negative control. $\mathrm{ph}=$ pharynx, ov $=$ ova, $\mathrm{t}=$ testes, $\mathrm{mp}=$ male pore, $\mathrm{fp}=$ female pore. Black bar $=1 \mathrm{~mm}(\mathbf{A}), 500 \mu \mathrm{m}(\mathbf{B}-\mathbf{D})$. 


\subsection{Offspring}

The high water and mucopolysaccharide content of the gelatinous matrix of the egg masses prevented histological studies on these samples. However, the egg masses of both P. maculata and Stylochoplana sp., and hatched larvae of P. maculata, were tested for TTX utilizing liquid chromatography-mass spectrometry (LC-MS; Table 1). To ascertain where TTX is localized in the egg masses of $P$. maculata, the outer gelatinous matrix, with and without the eggs, was tested. No TTX was detected in the gelatinous matrix with the eggs removed, thus it is assumed that TTX is invested only into the eggs. While this would be beneficial for the larvae once hatched, the lack of TTX in the gelatinous coating surrounding the eggs is at odds with the suggestion that TTX provides a protective function for the egg masses [12]. This, in conjunction with the observation of the sea star Patiriella regularis consuming Pleurobranchaea maculata egg masses (L. Salvitti pers. obs.), suggests that TTX does not act as a predator deterrent at this life stage.

Tetrodotoxin concentrations of egg masses from a Stylochoplana sp. kept in aquaria were higher than those $P$. maculata egg masses tested in this study, but still in the range of previously recorded TTX concentrations of $P$. maculata egg masses (max. $100 \mathrm{mg} \cdot \mathrm{kg}^{-1}$ ) [12]. It was not possible to localize TTX in egg masses of Stylochoplana sp. as these were only ca. $75 \mathrm{mg}$ making separation of the gelatinous matrix and eggs difficult. Tetrodotoxin has been shown to be sequestered in eggs and egg masses of other species including flatworms Planocera multitentaculata [47], California newts T. torosa [41], rough skin newts T. granulosa [49], horseshoe crabs Carcinoscorpius rotundicauda [50,51], blue ring octopuses $H$. maculosa [52] and H. lunulata [44], and frogs A. chiriquiensis [53]. The foremost ecological role suggested for TTX residing in the egg masses and offspring is for protection. A recent study by Itoi et al. [45] demonstrates this possibility by showing that several predatory fish species ingested toxic pufferfish (T. rubripes and T. niphobles) larvae, but promptly spat them out. Immunohistological techniques revealed the localization of TTX in the outer layer of larvae of both pufferfish species. Several other studies have also shown the presence of TTX in pufferfish eggs and gonads signaling a potential role for the toxin in progeny protection $[54,55]$.

Table 1. Tetrodotoxin (TTX) concentrations of egg masses and hatched larvae of Pleurobranchaea maculata (P.M.) collected from Pilot Bay, New Zealand on 9 September $2013(n=1)$ and average TTX concentrations in egg masses of Stylochoplana sp. (S.S.) kept in aquaria $(n=2)$.

\begin{tabular}{cc}
\hline Sample & TTX \\
\hline P.M egg mass (-eggs) & $\mathrm{ND}$ \\
P.M. egg mass (+eggs) & $3.7 \mathrm{mg} \cdot \mathrm{kg}^{-1}$ \\
P.M. larvae & $48.3 \mathrm{pg} \cdot$ indivdual $^{-1}$ \\
S.S. egg masses & $108 \pm 2 \mathrm{mg} \cdot \mathrm{kg}^{-1}$ \\
\hline
\end{tabular}




\section{Experimental Section}

\subsection{Specimen Collection}

Toxic P. maculata and Stylochoplana sp. specimens were collected from Pilot Bay, Tauranga, New Zealand ( $37^{\circ} 63^{\prime} 5^{\prime \prime} \mathrm{S}, 176^{\circ} 17^{\prime} 6^{\prime \prime}$ E). Pleurobranchaea maculata individuals were collected on 27 September 2012 and Stylochoplana sp. specimens on 12 September and 25 October 2013. Non-toxic P. maculata specimens were collected from Tasman Bay, New Zealand $\left(41^{\circ} 05^{\prime} \mathrm{S}\right.$, $173^{\circ} 06^{\prime}$ E) on 7 August 2012.

Egg masses from P. maculata were collected on 9 September 2013 from Pilot Bay and kept in an aerated aquarium for 3 days before freezing $\left(-20{ }^{\circ} \mathrm{C}\right)$ sections for TTX analysis. Egg masses were tested in their entirety and small sections were carefully scraped clean of egg capsules leaving only the gelatinous casing for testing. The remaining egg masses were left in the aquarium until hatching (day 7). A sample of larvae $(50 \mathrm{~mL})$ was centrifuged $(3000 \times \mathrm{g}, 10 \mathrm{~min})$, seawater removed, and frozen $\left(-20{ }^{\circ} \mathrm{C}\right)$ for TTX analysis. Additional subsamples $(50 \mathrm{~mL})$ of larvae were collected, fixed with ethanol, and used for enumeration to determine the number of individuals in each sample. Counts were conducted using a $5 \mathrm{~mL}$ chamber and a dissecting microscope (Olympus SZ60).

Twenty-three Stylochoplana sp. specimens were collected from Pilot Bay (7 June 2012) and transported to laboratory aquaria in individual small plastic containers with $50 \mathrm{~mL}$ of seawater. Specimens were maintained in aerated aquariums $(19 \mathrm{~L})$ with $14 \mathrm{~L}$ of filtered seawater $(0.22 \mu \mathrm{m})$. One individual laid two egg masses fourteen days after collection. Egg masses were removed from tanks and frozen $\left(-20^{\circ} \mathrm{C}\right)$ for TTX analysis.

\subsection{Histochemistry}

Pleurobranchea maculata were aseptically dissected. Small sections of the mantle tissue from P. maculata were removed, while the gonad and digestive tissues were kept intact due to the fragility of these tissues. Stylochoplana sp. specimens were left whole because of their small size (ave. $60 \mathrm{mg}$ ) and fixed flat using the techniques described in Newman and Cannon [56]. Briefly, Stylochoplana sp. specimens were transferred using a small artist brush to a piece of filter paper dampened with ambient seawater in order to encourage them to lie flat. Filter paper was then transferred into a container with frozen fixative ( $2 \%$ glutaraldehyde/4\% paraformaldehyde), which was left to melt.

Tissues and specimens were fixed overnight in $2 \%$ glutaraldehyde $/ 4 \%$ paraformaldehyde, dehydrated through increasing concentrations of ethanol to xylene, embedded in paraffin, and sectioned at 7 to $10 \mu \mathrm{m}$ thickness on a microtome (Leica RM 2055, Leica Biosystems, Wetzlar, Germany). Immunohistological sections were deparaffinized and rehydrated in ethanol before treatment with 3\% $\mathrm{H}_{2} \mathrm{O}_{2} / 10 \%$ methanol to remove endogenous peroxidase activity followed by incubation with normal goat serum (VectorLabs, Burlingame, CA, USA) to prevent non-specific binding. Both the $\mathrm{H}_{2} \mathrm{O}_{2}$ /methanol mixture and normal goat serum were diluted with $1 \times$ phosphate buffered saline (1× PBS, pH 7.2). Slides were then incubated with a TTX-specific monoclonal antibody (mAb) T20G10 diluted to $0.5 \mu \mathrm{g} \cdot \mathrm{mL}^{-1}$ [30] in concert with VECTASTAIN ${ }^{\circledR}$ ABC kit (VectorLabs, Burlingame, CA, USA) according to the manufacturer's instructions (Table 2). Visualization of the antigen-antibody complex was conducted using 3,3'-diaminobenzidine (DAB) substrate solution 
resulting in a brown color deposit. Sections were counterstained with Gill's II Hematoxylin (Surgipath $^{\circledR}$, Leica Biosystems, Wetzlar, Germany), mounted, and observed under a light microscope (Leica DMRE with plan fluorite lenses, Leica Biosystems, Wetzlar, Germany).

Table 2. Immunohistological incubation scheme. Steps were undertaken at room temperature unless otherwise specified. $\mathrm{PBS}=$ phosphate buffered saline, $\mathrm{mAB}=$ monoclonal antibody, $\mathrm{DAB}=3,3^{\prime}$-diaminobenzidine.

\begin{tabular}{ccc}
\hline Step & Solution & Time (min) \\
\hline 1. & $3 \% \mathrm{H}_{2} \mathrm{O}_{2} / 10 \%$ methanol & 10 \\
2. & $1 \times \mathrm{PBS}$ & $10 \times 3$ \\
3. & Normal Goat Serum (Vector Labs) & 20 \\
4. & $1 \times \mathrm{PBS}$ & $10 \times 3$ \\
5. & $\mathrm{mAB}$ T20G10* & Overnight at $4{ }^{\circ} \mathrm{C}$ \\
6. & $1 \times \mathrm{PBS}$ & $10 \times 3$ \\
7. & Biotinylated secondary antibody (anti-rabbit IgG) $*$ & 60 \\
8. & $1 \times \mathrm{PBS}$ & $10 \times 3$ \\
9. & $1 \times \mathrm{PBS}$ & 60 \\
10. & $\mathrm{DAB}$ & $10 \times 3$ \\
11. & DECTASTAIN ${ }^{\circledR} \mathrm{ABC}$ reagent $*$ & $2-5$ \\
12. & Deionized $\mathrm{H}_{2} \mathrm{O}$ & 5 \\
13. & Counterstain $($ Gill's II Hematoxylin) & 2 \\
\hline
\end{tabular}

* reagents diluted with $1 \times \mathrm{PBS}$, $\mathrm{pH} 7.2$, modified with $0.5 \%$ Triton $\mathrm{X}-100$ and $0.25 \% \mathrm{~m} / \mathrm{v}$ type $\mathrm{B}$ gelatin.

Some sections of Stylochoplana sp. and P. maculata mantle tissue were also stained with Gill's II hematoxylin (Surgipath ${ }^{\circledR}$; Leica Biosystems, Wetzlar, Germany) and eosin (Surgipath ${ }^{\circledR}$; Leica Biosystems, Wetzlar, Germany), and the Alcian Blue-Periodic Acid-Schiff (AB-PAS) method to differentiate between neutral and acidic mucins [57]. For AB-PAS staining, paraffin sections were rehydrated, stained with alcian blue $(5 \mathrm{~min})$, rinsed with distilled water, flooded with $1 \%$ periodic acid ( $2 \mathrm{~min}$ ) and rinsed again. Slides were then immersed in Schiff's reagent ( $8 \mathrm{~min}$ ) and washed in running water $(10 \mathrm{~min})$. Sections were lightly counterstained with Mayer's hematoxylin ( $2 \mathrm{~min})$ before a final rinse with water. Sections were then dehydrated in an ascending ethanol series, cleared in xylene, mounted in D.P.X (Merck Millipore, Billerica, MA, USA), and observed under a light microscope (Leica DMRE with plan fluorite lenses, Leica Biosystems, Wetzlar, Germany).

\subsection{Tetrodotoxin Analysis}

Entire egg masses of Stylochoplana sp., specimens and sub-samples of egg masses from P. maculata, both with and without eggs, and hatched larvae were extracted for TTX. Samples (ca. $0.1 \mathrm{~g})$ were first diluted 1:10 (w:v) with Milli-Q containing 0.1\% v/v acetic acid. Each sample was manually homogenized with a glass pestle and vortexed to ensure complete disruption of tissues. Samples were centrifuged $(3000 \times g, 10 \mathrm{~min})$ and an aliquot of the supernatant was removed. This was diluted 1:10 with $100 \%$ methanol containing $0.1 \% \mathrm{v} / \mathrm{v}$ acetic acid and frozen $\left(-20{ }^{\circ} \mathrm{C}\right)$ for at least $1 \mathrm{~h}$. Samples were then centrifuged $(3000 \times \mathrm{g}, 10 \mathrm{~min})$ and diluted $1: 4$ with $100 \%$ methanol containing $0.1 \% \mathrm{v} / \mathrm{v}$ acetic acid and analyzed for TTX using LC-MS as described in McNabb et al. [27]. 


\section{Conclusions}

Tetrodotoxin was found to be sequestered in the mantle, reproductive tissues, eggs, and larvae of P. maculata. Definitive characterization of the type of TTX-containing cells in the mantle of P. maculata is difficult to ascertain with paraffin techniques, and electron microscopy would greatly aid in identifying cell types and elucidating their potential functions. Tetrodotoxin localization in the digestive tissue could be indicative of a dietary source of TTX in this species. The de novo synthesis or sequestration of secondary metabolites from prey for use as a defense mechanism in Opisthobranchs is a well-known phenomenon (reviewed in [31]). The sequestration of TTX in the mantle, eggs, and larvae may be suggestive of a defensive role in $P$. maculata.

Localization of TTX in the pharynx, ova, and egg masses of Stylochoplana sp. could be indicative of ecological roles including aiding in capturing prey and protection of offspring, and further studies are required.

The methods by which P. maculata and Stylochoplana sp. sequester TTX are unknown. Immunohistologically-stained sections of $P$. maculata show that low concentrations of TTX are present throughout most tissues, while TTX is exclusively localized in the ova and pharynx of the Stylochoplana sp. This could be a product of differing anatomy (coelomate verses acoelomate) or that sequestration techniques differ between the two species. Tetrodotoxin-binding proteins have been isolated from a number of invertebrates including horseshoe crabs [58], xanthid crabs [59], and several gastropods [60]. Determining if these proteins are present in P. maculata or Stylochoplana sp. would assist in understanding the transfer and transport of TTX in these organisms.

\section{Acknowledgments}

This research was supported by an award from the Marsden fund of the Royal Society of New Zealand (UOW1002) to S.C.C. and S.A.W. The T20G10 anti-TTX monoclonal antibody was kindly provided by Mark Poli (U.S Army Medical Research Institute of Infectious Diseases). The authors would like to thank Paul McNabb (Cawthron) for TTX analysis, Dudley Bell, Warrick Powrie, Rex Fairweather, and David Culliford (Waikato University) for their help with the collection of specimens and Barry O'Brien, Pawel Olszewski, and Linda Peters (Waikato University) for microscopy and histological assistance.

\section{Author Contributions}

Experiments were designed by Lauren R. Salvitti, Susanna A. Wood, and S. Craig Cary, and conducted by Lauren R. Salvitti and Leigh Winsor. All authors contributed to data analysis and the writing of the manuscript.

\section{Conflicts of Interest}

The authors declare no conflict of interest. 


\section{References}

1. Noguchi, T.; Arakawa, O.; Takatani, T. TTX accumulation in pufferfish. Comp. Biochem. Physiol. D Genomics Proteomics 2006, 1, 145-152.

2. Noguchi, T.; Arakawa, O. Tetrodotoxin-Distribution and accumulation in aquatic organisms, and cases of human intoxication. Mar. Drugs 2008, 6, 220-242.

3. Noguchi, T.; Ebesu, J.S.M. Puffer poisoning: Epidemiology and treatment. J. Toxicol. Toxin Rev. 2001, 20, 1-10.

4. Chau, R.; Kalaitzis, J.A.; Neilan, B.A. On the origins and biosynthesis of tetrodotoxin. Aquat. Toxicol. 2011, 104, 61-72.

5. Miyazawa, K.; Noguchi, T. Distribution and origin of tetrodotoxin. Toxin Rev. 2001, 20, 11-33.

6. Stokes, A.N.; Ducey, P.K.; Neuman-Lee, L.; Hanifin, C.T.; French, S.S.; Pfrender, M.E.; Brodie, E.D., III; Brodie, E.D., Jr. Confirmation and distribution of tetrodotoxin for the first time in terrestrial invertebrates: Two terrestrial flatworm species (Bipalium adventitium and Bipalium kewense). PLoS One 2014, 9, e100718.

7. Wang, X.-J.; Yu, R.-C.; Luo, X.; Zhou, M.-J.; Lin, X.-T. Toxin-screening and identification of bacteria isolated from highly toxic marine gastropod Nassarius semiplicatus. Toxicon 2008, 52, $55-61$.

8. Wu, Z.L.; Xie, L.P.; Xia, G.L.; Zhang, J.F.; Nie, Y.C.; Hu, J.C.; Wang, S.J.; Zhang, R.Q. A new tetrodotoxin-producing actinomycete, Nocardiopsis dassonvillei, isolated from the ovaries of puffer fish Fugu rubripes. Toxicon 2005, 45, 851-859.

9. Yasumoto, T.; Yasumura, D.; Yotsu, M.; Michishita, T.; Endo, A.; Kotaki, Y. Bacterial production of tetrodotoxin and anhydrotetrodotoxin. Agric. Biol. Chem. 1986, 50, 793-795.

10. Daly, J.W.; Padgett, W.L.; Saunders, R.L.; Cover, J.F. Absence of tetrodotoxins in a captive-raised riparian frog, Atelopus varius. Toxicon 1997, 35, 705-709.

11. Noguchi, T.; Maruyama, J.; Hashimoto, K.; Narita, H. Tetrodotoxin in the starfish Astropecten polyacanthus, in association with toxification of a trumpet shell, "Boshubora" Charonia sauliae. Bull. Jpn. Soc. Sci. Fish 1982, 48, 1173-1177.

12. Wood, S.A.; Casas, M.; Taylor, D.; McNabb, P.; Salvitti, L.; Ogilvie, S.; Cary, S.C. Depuration of tetrodotoxin and changes in bacterial communities in Pleurobranchea maculata adults and egg masses maintained in captivity. J. Chem. Ecol. 2012, 38, 1342-1350.

13. Cheng, C.A.; Hwang, D.F.; Tsai, Y.H.; Chen, H.C.; Jeng, S.S.; Noguchi, T.; Ohwada, K.; Hashimoto, K. Microflora and tetrodotoxin-producing bacteria in a gastropod, Niotha clathrata. Food Chem. Toxicol. 1995, 33, 929-934.

14. Hwang, D.F.; Arakawa, O.; Saito, T.; Noguchi, T.; Simidu, U.; Tsukamoto, K.; Shida, Y.; Hashimoto, K. Tetrodotoxin-producing bacteria from the blue-ringed octopus Octopus maculosus. Mar. Biol. 1989, 100, 327-332.

15. Noguchi, T.; Hwang, D.F.; Arakawa, O.; Sugita, H.; Deguchi, Y.; Shida, Y.; Hashimoto, K. Vibrio alginolyticus, a tetrodotoxin-producing bacterium, in the intestines of the fish Fugu vermicularis vermicularis. Mar. Biol. 1987, 94, 625-630.

16. Yang, G.; Xu, J.; Liang, S.; Ren, D.; Yan, X.; Bao, B. A novel TTX-producing Aeromonas isolated from the ovary of Takifugu obscurus. Toxicon 2010, 56, 324-329. 
17. Cardall, B.L.; Brodie, E.D.; Hanifin, C.T. Secretion and regeneration of tetrodotoxin in the rough-skin newt (Taricha granulosa). Toxicon 2004, 44, 933-938.

18. Hanifin, C.T.; Brodie, E.D., III; Brodie, E.D., Jr. Tetrodotoxin levels of the rough-skin newt, Taricha granulosa, increase in long-term captivity. Toxicon 2002, 40, 1149-1153.

19. Mebs, D.; Arakawa, O.; Yotsu-Yamashita, M. Tissue distribution of tetrodotoxin in the red-spotted newt Notophthalmus viridescens. Toxicon 2010, 55, 1353-1357.

20. Tsuruda, K.; Arakawa, O.; Kawatsu, K.; Hamano, Y.; Takatani, T.; Noguchi, T. Secretory glands of tetrodotoxin in the skin of the Japanese newt Cynops pyrrhogaster. Toxicon 2002, 40, 131-136.

21. Tanu, M.B.; Mahmud, Y.; Arakawa, O.; Takatani, T.; Kajihara, H.; Kawatsu, K.; Hamano, Y.; Asakawa, M.; Miyazawa, K.; Noguchi, T. Immunoenzymatic visualization of tetrodotoxin (TTX) in Cephalothrix species (Nernertea: Anopla: Palaeonemertea: Cephalotrichidae) and Planocera reticulata (Platyhelminthes: Turbellaria: Polycladida: Planoceridae). Toxicon 2004, 44, 515-520.

22. Mahmud, Y.; Arakawa, O.; Ichinose, A.; Tanu, M.B.; Takatani, T.; Tsuruda, K.; Kawatsu, K.; Hamano, Y.; Noguchi, T. Intracellular visualization of tetrodotoxin (TTX) in the skin of a puffer Tetraodon nigroviridis by immunoenzymatic technique. Toxicon 2003, 41, 605-611.

23. Mahmud, Y.; Okada, K.; Takatani, T.; Kawatsu, K.; Hamano, Y.; Arakawa, O.; Noguchi, T. Intra-tissue distribution of tetrodotoxin in two marine puffers Takifugu vermicularis and Chelonodon patoca. Toxicon 2003, 41, 13-18.

24. Tanu, M.B.; Mahmud, Y.; Takatani, T.; Kawatsu, K.; Hamano, Y.; Arakawa, O.; Noguchi, T. Localization of tetrodotoxin in the skin of a brackishwater puffer Tetraodon steindachneri on the basis of immunohistological study. Toxicon 2002, 40, 103-106.

25. Williams, B.L.; Stark, M.R.; Caldwell, R.L. Microdistribution of tetrodotoxin in two species of blue-ringed octopuses (Hapalochlaena lunulata and Hapalochlaena fasciata) detected by fluorescent immunolabeling. Toxicon 2012, 60, 1307-1313.

26. Williams, B.L.; Hanifin, C.T.; Brodie, E.D., Jr.; Brodie, E.D., III. Tetrodotoxin affects survival probability of rough-skinned newts (Taricha granulosa) faced with TTX-resistant garter snake predators (Thamnophis sirtalis). Chemoecology 2010, 20, 285-290.

27. McNabb, P.; Selwood, A.I.; Munday, R.; Wood, S.A.; Taylor, D.I.; MacKenzie, L.A.; van Ginkel, R.; Rhodes, L.L.; Cornelisen, C.; Heasman, K.; et al. Detection of tetrodotoxin from the grey side-gilled sea slug-Pleurobranchaea maculata, and associated dog neurotoxicosis on beaches adjacent to the Hauraki Gulf, Auckland, New Zealand. Toxicon 2010, 56, 466-473.

28. Wood, S.A.; Taylor, D.I.; McNabb, P.; Walker, J.; Adamson, J.; Cary, S.C. Tetrodotoxin concentrations in Pleurobranchaea maculata: Temporal, spatial and individual variability from New Zealand populations. Mar. Drugs 2012, 10, 163-176.

29. Salvitti, L.R.; Wood, S.A.; Taylor, D.I.; McNabb, P.; Cary, S.C. First identification of tetrodotoxin (TTX) in the flatworm Stylochoplana sp; a source of TTX for the sea slug Pleurobranchaea maculata. Toxicon 2015, 95, 23-29.

30. Rivera, V.R.; Poli, M.A.; Bignami, G.S. Prophylaxis and treatment with a monoclonal antibody of tetrodotoxin poisoning in mice. Toxicon 1995, 33, 1231-1237.

31. Putz, A.; Koenig, G.M.; Waegele, H. Defensive strategies of Cladobranchia (Gastropoda, Opisthobranchia). Nat. Prod. Rep. 2010, 27, 1386-1402. 
32. Wagele, H.; Klussmann-Kolb, A. Opisthobranchia (Mollusca, Gastropoda)—More than just slimy slugs. Shell reduction and its implications on defence and foraging. Front. Zool. 2005, 2, 1-18.

33. Wagele, H.; Ballesteros, M.; Avila, C. Defensive glandular structures in opisthobranch molluscs - From histology to ecology. In Oceanography and Marine Biology-An Annual Review; Gibson, R.N., Atkinson, R.J.A., Gordon, J.D.M., Eds.; Taylor \& Francis: Abingdon, UK, 2006; pp. 197-276.

34. Thompson, T.E. Detection of epithelial acid secretions in marine molluscs: Review of techniques, and new analytical methods. Comp. Biochem. Physiol. A Physiol. 1983, 74, 615-621.

35. Thompson, T.E. Acid secretion in the Pacific Ocean gastropods. Aust. J. Zool. 1969, 17, 755-764.

36. Cattaneo-Vietti, R.; Angelini, S.; Gaggero, L.; Lucchetti, G. Mineral composition of nudibranch spicules. J. Molluscan Stud. 1995, 61, 331-337.

37. Derby, C.D. Escape by inking and secreting: Marine molluscs avoid predators through a rich array of chemicals and mechanisms. Biol. Bull. 2007, 213, 274-289.

38. Pawlik, J.R. Marine invertebrate chemical defenses. Chem. Rev. 1993, 93, 1911-1922.

39. Willan, R.C. New Zealand side-gilled sea slugs (Opisthobranchia: Notaspidea: Pluerobranchidae). Malacologia 1983, 23, 221-270.

40. Itoi, S.; Yoshikawa, S.; Tatsuno, R.; Suzuki, M.; Asahina, K.; Yamamoto, S.; Takanashi, S.; Tomohiro, T.; Arakawa, O.; Sakakura, Y.; et al. Difference in the localization of tetrodotoxin between the female and male pufferfish Takifugu niphobles, during spawning. Toxicon 2012, 60, 1000-1004.

41. Mosher, H.S.; Fuhrman, F.A.; Buchwald, H.D.; Fischer, H.G. Tarichatoxin-tetrodotoxin: A potent neurotoxin. Sci. New Ser. 1964, 144, 1100-1110.

42. Pires, O.R.; Sebben, A.; Schwartz, E.F.; Largura, S.W.R.; Bloch, C.; Morales, R.A.V.; Schwartz, C.A. Occurrence of tetrodotoxin and its analogues in the Brazilian frog Brachycephalus ephippium (Anura: Brachycephalidae). Toxicon 2002, 40, 761-766.

43. Yotsu, M.; Iorizzi, M.; Yasumoto, T. Distribution of tetrodotoxin, 6-epitetrodotoxin, and 11-deoxytetrodotoxin in newts. Toxicon 1990, 28, 238-241.

44. Williams, B.L.; Hanifin, C.T.; Brodie, E.D., Jr.; Caldwell, R.L. Ontogeny of tetrodotoxin levels in blue-ringed octopuses: Maternal investment and apparent independent production in offspring of Hapalochlaena lunulata. J. Chem. Ecol. 2011, 37, 10-17.

45. Itoi, S.; Yoshikawa, S.; Asahina, K.; Suzuki, M.; Ishizuka, K.; Takimoto, N.; Mitsuoka, R.; Yokoyama, N.; Detake, A.; Takayanagi, C.; et al. Larval pufferfish protected by maternal tetrodotoxin. Toxicon 2014, 78, 35-40.

46. Khor, S.; Wood, S.A.; Salvitti, L.; Taylor, D.I.; Adamson, J.; McNabb, P.; Cary, S.C. Investigating diet as the source of tetrodotoxin in Pleurobranchaea maculata. Mar. Drugs 2013, $12,1-12$.

47. Miyazawa, K.; Jeon, J.K.; Noguchi, T.; Ito, K.; Hashimoto, K. Distribution of tetrodotoxin in the tissues of the flatworm Planocera multitentaculata (Platyhelminthes). Toxicon 1987, 25, 975-980.

48. Ritson-Williams, R.; Yotsu-Yamashita, M.; Paul, V.J. Ecological functions of tetrodotoxin in a deadly polyclad flatworm. Proc. Natl. Acad. Sci. USA 2006, 103, 3176-3179.

49. Hanifin, C.T.; Brodie, E.D., III; Brodie, E.D., Jr. Tetrodotoxin levels in eggs of the rough-skin newt, Taricha granulosa, are correlated with female toxicity. J. Chem. Ecol. 2003, 29, 1729-1739. 
50. Kungsuwan, A.; Nagashima, Y.; Noguchi, T.; Shida, Y.; Suvapeepan, S.; Suwansakornkul, P.; Hashimoto, K. Tetrodotoxin in the horseshoe crab Carcinoscorpius rotundicauda inhabiting Thailand. Nippon Suisan Gakkaishi 1987, 53, 261-266.

51. Tanu, M.B.; Noguchi, T. Tetrodotoxin as a toxic principle in the horseshoe crab Carcinoscorpius rotundicauda collected from Bangladesh. J. Food Hyg. Soc. Jpn. 1999, 40, 426-430.

52. Sheumack, D.D.; Howden, M.E.H.; Spence, I. Occurrence of a tetrodotoxin-like compound in the eggs of the venomous blue-ringed octopus (Hapalochlaena maculosa). Toxicon 1984, 22, 811-812.

53. Pavelka, L.A.; Kim, Y.H.; Mosher, H.S. Tetrodotoxin and tetrodotoxin-like compounds from the eggs of the Costa Rican frog, Atelopus chiriquiensis. Toxicon 1977, 15, 135-139.

54. Matsumura, K. Tetrodotoxin as a pheromone. Nature 1995, 378, 563-564.

55. Nagashima, Y.; Mataki, I.; Toyoda, M.; Nakajima, H.; Tsumotoo, K.; Shimakura, K.; Shioma, K. Change in tetrodotoxin content of the puffer fish Takifugu rubripes during seed production from fertilized eggs to juveniles. Food Hyg. Saf. Sci. 2010, 51, 48-51.

56. Newman, L.J.; Cannon, L.R.G. Marine Flatworms: The World of Polyclad Flatworms; CSIRO Publishing: Melbourne, Victoria, Australia, 2003.

57. Kiernan, J. Histological and Histochemical Methods: Theory and Practice, 4th ed.; Cold Spring Harbor Laboratory Press: Cold Spring Harbor, NY, USA, 2008.

58. Ho, B.; Yeo, D.S.A.; Ding, J.L. A tetrodotoxin neutralizing system in the hemolymph of the horseshoe-crab, Carcinoscorpius rotundicauda. Toxicon 1994, 32, 755-762.

59. Llewellyn, L.E. Haemolymph protein in xanthid crabs: Its selective binding of saxitoxin and possible role in toxin bioaccumulation. Mar. Biol. 1997, 128, 599-606.

60. Hwang, P.-A.; Tsai, Y.-H.; Lin, H.-P.; Hwang, D.-F. Tetrodotoxin-binding proteins isolated from five species of toxic gastropods. Food Chem. 2007, 103, 1153-1158.

(C) 2015 by the authors; licensee MDPI, Basel, Switzerland. This article is an open access article distributed under the terms and conditions of the Creative Commons Attribution license (http://creativecommons.org/licenses/by/4.0/). 